\title{
The Impact of Entrepreneurial Orientation on Access to Debt Finance and Performance of Small and Medium Enterprises in South Africa
}

\author{
Olawale Fatoki \\ Department of Business Management, Auckland Park Kingsway Campus, \\ University of Johannesburg, Johannesburg, South Africa \\ E-mail: olawalefatoki@gmail.com
}

KEYWORDS Entrepreneurial Orientation. Debt Finance. Performance. Mediation. South Africa

ABSTRACT This study investigates the impact of entrepreneurial orientation (EO) on access to debt finance and performance of small and medium enterprises (SMEs). Inaccessibility to debt finance is one of the primary causes of failure and weak performance of SMEs in South Africa. The survey area was King William's Town and East London in the Eastern Cape of South Africa. Data was collected through the use of self-administered questionnaires in a survey. Data was analysed through the use of descriptive statistics, correlation and regression. The Cronbach's alpha was used to measure reliability. The results indicate that there is a significant positive relationship between $\mathrm{EO}$ and access to debt finance and the performance of SMEs. The results also indicate that access to debt finance partially mediates the relationship between EO and the performance of SMEs. Recommendations on how SMEs can improve EO such as training and incorporating EO in the reward system are suggested.

\section{INTRODUCTION}

According to Abor and Quartey (201: 220) small and medium enterprises (SMEs) are of great socio-economic significance. In South Africa, SMEs have been identified by the government as a priority in increasing jobs in order to reduce the high unemployment rate which is currently estimated at $23.9 \%$ (Statistics South Africa 2012). In addition, SMEs have an important role to play in reducing wealth inequalities and improving the economic growth of South Africa (Pahad 2008). Adeniran and Johnston (2011) note that despite the highlighted importance of the SME sector, it is estimated that the failure rate of SMEs in South Africa is between $70 \%$ and $80 \%$. The high failure rate casts doubt on this sector's ability to create sustainable employment and reduce poverty. Bowen et al. (2009: 17) state that given this high failure rate, it becomes vital to research into the factors that are required to enable SMEs to survive and improve their performance.

Rogerson (2008: 62) observes that one of the primary causes of SME failure in South Africa is the non-availability of external finance. Awang et al. (2010: 15) add that the reasons for the failure among SMEs are due to the weaknesses in their strategic framework to harmonize firm's entrepreneurship strategy. According to Aktan and Bulut (2008: 74) and Chen et al. (2008: 217), today's firm managers are faced with rapidly changing and fast-paced competitive environment. To cope with such challenges an entrepreneurial approach to strategy making may be vital for organisational success. An entrepreneurial strategy making process referred to as entrepreneurial orientation (EO) is said to exist for firms that engages in product or market innovations, undertakes risky ventures and is said to come up with proactive innovations beating competitors to the punch.

Van Geenhuizen et al. (2008) note that EO has emerged as a possible antidote to the problems facing businesses that wish to achieve a sustained competitive advantage. Swidi and Mahmood (2011: 30) and Razak (2011: 252) observe that although EO is almost always used to describe a situation occurring in large organizations, it is just as essential for smaller firms. Thus, there is a particular interest in enriching our understanding of EO in an SME context. Ligthelm (2011) suggests that SMEs in South Africa suffer from severe competitive pressures from large firms implying that SMEs operate in a hostile rather than a benign environment. Thus EO can be of significant importance in improving the performance and reducing the high failure rates of SMEs in South Africa. 
Empirical literature on the impact of EO on firm performance remains inconclusive. Studies such as Callaghan and Venter (2011: 29) and Zampetakis et al. (2011: 905) find that firms with a more entrepreneurial orientation (EO) perform better than firms that are not. Moreno and Casillas (2008: 507) on the other hand did not find any significant positive impact of EO on firm growth. This raises the question of whether EO is always an appropriate strategic orientation or if its relationship with performance is always positive. According to Chen et al. (2008: 216), EO needs access to financial capital for it to be effective. Lucey (2010: 3 ) finds that internal financial capital is usually inadequate for the growth of SMEs. Hence, SMEs have to rely on external financial capital. The two primary sources of external finance for SMEs are equity and debt. External equity is usually not available for SMEs. This makes many SMEs dependent on debt (Blumberg and Letterie 2008: 188). Huang et al. (2011: 3049) find a positive relationship between EO and social capital. Social capital can bring resources and support to entrepreneurs. This suggests that EO can improve access to financial resources by firms (Zampetakis et al. 2010: 906).

A meta analysis of the empirical literature on EO in South Africa revealed that most studies have focused on large firms. Kriel (2008:18) focused on the nature of entrepreneurial orientation in the South African Liquor industry. Scheepers et al. (2008:52) focused on the entrepreneurial orientation of companies listed on the Johannesburg Stock Exchange and companies operating in the Information and Communication technology industry. Gronewald and van Vuuren (2011:1) assessed entrepreneurial intention and the level of innovation in the South African short-term insurance industry. Limited empirical studies (Callaghan and Venter 2011:28; Farrington and Matchaba-Hove 2011:4) have focused on the impact of entrepreneurial orientation on performance of SMEs in South Africa. These studies find significant positive relationships between EO (or different components of EO) and the performance of SMEs. However, no empirical study in South Africa has investigated whether EO positively impacts on access to debt finance by SMEs and whether access to debt finance can mediate the relationship between $\mathrm{EO}$ and the performance of SMEs.

\section{The Objectives of the Study}

The objectives of the study are:

- To investigate the relationship between EO and access to debt finance by SMEs

- To investigate the relationship between EO and the performance of SMEs

- To investigate the relationship between access to debt finance and performance of SMEs

- To investigate whether access to debt finance mediates the relationship between EO and the performance of SMEs

\section{Theory and Hypotheses Development}

\section{Definition of Entrepreneurial Orientation}

According to Covin and Wales (2011: 1), a lot of terminologies are often used by researchers to denote the concept entrepreneurial orientation (EO). These include corporate entrepreneurship, corporate venturing, intrapreneuring and internal entrepreneurship. Covin and Wales (2011) point out that the term EO does not have a universally accepted definition. Moreno and Casillas (2008: 508) note that EO is the organisational decision-making proclivity favouring entrepreneurial activities. EO is a way to act entrepreneurially within an established organisation. Van Geenhuizen et al. (2008) note that autonomy, innovativeness, risk taking, proactiveness, and competitive aggressiveness as a set of behaviours that reflect EO. Other entrepreneurship researchers such as Covin and Lumpkin (2011: 856) hold that EO is a process through which individuals in an established firm pursue entrepreneurial opportunities to innovate without regard to the level and nature of currently available resources. EO is the effort to extend an organization's competitive advantage.

\section{Theoretical Framework of Entrepreneurial Orientation}

Covin and Wales (2011: 2) observe that the theoretical foundation of EO research can be traced to the work of Mintzberg (1973), Khandwalla (1976, 1977), Miller (1983) Covin and Slevin (1989), Miller and Friesen (1982) and Lumpkin and Dess (1996). Mintzberg (1973: 45) suggests three modes of strategy-making: the planning, the adaptive and the entrepreneurial. 
The planning mode involves systematic information gathering for situational analysis generating alternate strategies and selection of appropriate strategy. The adaptive mode focuses on reactive solutions than proactive search for new opportunities. The entrepreneurial mode is based on active search for entrepreneurial opportunities and growth. Khandwalla (1976/1977: 23) points out that entrepreneurial management style refers to bold, risky and aggressive approach to decision-making in contrast to a more cautious stability-oriented approach. Covin and Slevin (1989: 76) find that firms operating in hostile competitive environments, characterised by intense rivalry among firms tend to adopt innovations with greater frequency than firms operating in more benign competitive settings. Miller (1983: 770) observes that an entrepreneurial firm is one that engages in product market innovation, undertakes somewhat risky ventures, and is first to come up with proactive innovations, beating competitors to the punch. Miller (1983: 771) used the dimensions of innovativeness, risk taking and proactiveness to characterize and test entrepreneurial orientation.

Lumpkin and Dess (1996: 137) expanded the numbers of dimensions that characterise EO to five by adding competitive aggressiveness and autonomy. Competitive aggressiveness refers to how firms relate to competitors in the market place. Autonomy refers to the key independent actions of an individual in bringing forth an idea or vision and carrying it through to completion. According to Covin and Wales (2011: 1), the works of these researchers established EO as a managerial disposition rooted in decision-making. EO is an organisational-level phenomenon involving key decisions made on behalf of the entire organisation. Entrepreneurial firms are those in which top managers have entrepreneurial management styles as evidenced by the firms' strategic decisions and operating management philosophy.

\section{EO and Access to Debt Finance by SMES}

Herrington et al. (2009) point out that access to finance is a major problem for the South African entrepreneur. Lack of financial support is one of the causes of weak performance and failure of SMEs in South Africa. Zou et al. (2009: 296) use the Resource Based View (RBV) to demonstrate the importance of financial capital to the performance of SMEs. Access to financial capital to purchase fixed and current assets is important to a sustaining a firm's competitive advantage. According to Atieno (2009: 34), a vast majority of SMEs depend on internal finance (contribution from the owners, family and friends). However, the growth of SMEs is constrained by dependence on internal finance. In contrast, firms that make use of external funds exhibit growth rates far above what can be supported by internal finance. Therefore, SMEs often need capital from external sources.

According to Lucey (2010: 3), the two primary sources of external finance for new SMEs are equity and debt. External equity in the form of venture capital or the stock exchange is usually not available for SMEs. According to the South African Venture Capital Association (2008) there are at least 65 venture capital funds in South Africa controlling a total of R29 billion with an average investment size of R15.4 million. However, venture investment with a SME focus is approximately R1.1 billion which is only $3.8 \%$ of the funds. This indicates that the availability of external equity is limited for SMEs. According to Blumberg and Letterie (2008: 188), the lack of external equity makes many SMEs dependent on debt finance especially bank loans and trade credit.

Tang et al. (2008: 222) argue that without adequate resources, all strategic intentions and plans are going to fail. Covin and Lumpkin (2011: 855 ) point out that the dimensions of entrepreneurial orientation involve a high level of resources or capital commitments by the firm. Haung et al. (2011: 3049) note that firms characterised by risk-taking behaviour often make large resource commitments with a view of securing high returns by seizing opportunities in the market place. In addition, entrepreneurs depicting risk-taking behaviour show more willingness to take on risky resources such as external financial capital. Firms that are proactive and competitively aggressive have forward-looking, opportunity seeking perspective. Proactiveness is important in establishing links and networks with the various sources of finance. In addition as pointed out by $\mathrm{Li}$ et al. (2008: 115) innovativeness refers to a firm's ability to engage and support new ideas, novelty and experimentation. Innovation requires the commitment of financial resources. Mukiri (2011) argues that firms that have an entrepreneurial orienta- 
tion are more prone to focus attention and effort toward emerging opportunities such as links with the providers of capital. This suggests that for EO to be successful, a firm will need to commit financial resources. In addition, firms that have an EO strategic focus may be able to access debt capital due to better relationships with the providers of debt capital. Consequently, it is hypothesised that: there is a positive relationship between EO and access to debt finance by SMEs.

\section{EO and Performance of SMES}

Ireland et al. (2009: 20) observe that EO has been widely touted by researchers alike as an effective means of improving firm financial performance. The implicit logic behind the pervasive belief in the value of EO seems to be that the key elements of entrepreneurial orientation will help firms in identifying and pursuing lucrative product/market opportunities and in providing bases for achieving superior competitive positions. Aktan et al. (2008: 69) find that EO activities in firms have resulted in diversified products and markets, as well as being instrumental to producing impressive financial results. In addition, EO is positively linked to intangible outcomes, like knowledge, skill development, and job satisfaction. Awang et al. (2010: 13) point out that the ability of a firm to stay competitive is directly related to a firm's intensity to take calculated risks. Fairoz et al. (2010: 34) and Hung and Chiang (2010) point out that innovation in the firm of new products, services and processes or in a combination of theses can lead to sustainable competitive advantage.

Empirical literature is inconclusive about the impact of EO on firm performance. Moreno and Casillas (2008) find no direct relationship between EO and growth of a firm. Farrington and Matchaba-Hove (2011) find that not all the dimensions of EO positively impact on firm success. Though, empirical literature about the impact of EO on firm performance is inconclusive, the argument of this study is that the dimensions of EO such as competitive aggressiveness and innovation should give an SME the competitive edge. Consequently, it is hypothesised that there is a positive relationship between $\mathrm{EO}$ and the performance of SMEs.

\section{Debt Finance and Firm Performance}

Modigliani and Miller (1963:433) in their seminar paper on the tax advantages of debt, argue that interest payments on debt are tax- deductible whereas dividend payments on equity do not enjoy such tax advantages. Therefore, in a world of tax-deductible interest payments, firms can use debt to lower their costs of capital and maximise their profitability. This is known as the leverage effect of debt. However, leverage also introduces an element of financial risk to the firm. According to Abor and Quartey (2010:220), the use of financial leverage (that is, the use of debt) can be positive or negative. Leverage is positive when a firm earns a higher return on assets that is greater than the interest rate on debt. Leverage is negative if the return on assets is lower than the interest rate on debt. Literature on the impact of debt on the performance of firms is inconclusive. Studies such as Eriotis et al. (2002:89) and Bartholdy and Mateus (2006:5) find that the use of debt has a negative impact on the profitability of firms. Other studies such as Negash (2002:119) and Hadlock and James (2002:1385) find a significant positive relationship between the use of debt and firm performance.

According to the South African Reserve Bank (2011:26), the Repo rate has reduced over the years to $5.5 \%$ in South Africa. The Repo rate is the price at which the central bank lends cash to the banking system and is the most important indicator of short-term interest rates. Gordhan (2011) points out that the cost of borrowing has reduced significantly in South Africa with the prime interest rate of $9 \%$ at a 30 year low. This suggests that SMEs that have access to debt should be able to obtain a positive leverage. Consequently, it is hypothesised that there is a positive relationship between the use of debt and the performance of SMEs.

\section{The Mediating Role of Access to Debt Finance}

Zampetakis et al. (2010: 903) point if EO is strongly linked to the performance, it does not always have a positive impact on it. It all depends on the context. EO needs to be associated to other business practices in order to strengthen its positive impacts on firm performance. Empirical literature has investigated the 
mediating effect of EO on performance. Li et al. (2008:113) finds that knowledge creation mediates the relationship between EO and performance. Rodrigues (2008) provides evidence of the mediating effect of EO on market orientation and firm performance. Hartsfield et al. (2008: 12) find that firms with high level of EO are able to engage in strategic planning, identify customer needs and are able to identify new opportunities. In addition, firms that have access to debt should be able to improve their performance. Thus access to debt finance can play the role of intermediate variable which can mediate the relationship between EO and the performance of SMEs. Consequently, it is hypothesised that: access to debt finance mediates the relationship between EO and the performance of SMEs.

\section{RESEARCH METHODOLOGY}

\section{Data Collection}

The empirical approach consists of data collection through the use of self- administered questionnaires in a survey. The study was conducted in King Williams' Town and East London in the Eastern Cape Province of South Africa. Field agents from a firm of professional data collection agency helped to collect data. Most of the firms in the Eastern Cape are SMEs. Three hundred SMEs were identified through the use of convenience sampling method. The names and addresses of the firms were obtained from the Yellow Pages Telephone Directory. One hundred and eighteen SMEs participated in the research. Both Likert scale questions and dichotomous questions were used to elicit responses from the respondents. Kolmogorov-Smirnov test was used to measure the normality of the data. There were only four cases of missing values and pairwise deletion method was used to treat the missing values. Statistical analysis included descriptive statistics, factor analysis, Pearson correlation and regression analysis. To ensure validity and reliability a panel of experts was used to evaluate the research instrument for conceptual clarity. A pilot study was conducted on the survey instrument used in this research with 20 owners of SMEs in order to ensure face and content validity. The pilot study led to some modifications to the questionnaire The Cronbach's alpha was used as a test of reliabil- ity. Data collection took place between March and September 2011. In order to ensure that the respondents could respond accurate to the research questionnaire items, the owners or senior managers of the firms were targeted for data collection. Owners or top managers are typically the most knowledgeable persons regarding their firms' strategies and overall business situations. Owners and top managers were assured of confidentiality with regard to the data collected.

\section{Measuring Entrepreneurial Orientation}

According to Covin and Wales (2011: 9), there are four main models to measure entrepreneurial orientation. These are: (1) the Miller/ Covin and Slevin (1989) EO scale; (2) an alternative first-order reflecting scale corresponding to Miller's (1983) composite view of EO (3) the Hughes and Morgan (2007) EO scale; and (4) a "Type 11" second-order formative EO scale (that is, reflective first order, formative second order). In the Miller/Covin and Slevin (1989) scale, EO is measured as a basic, unidimensional strategic orientation and the nine items of the Miller/Covin and Slevin scale are jointly aggregated at the model's initial and only step. The alternative firstorder reflective scale of EO stays true to Miller's (1983) original three-sub-dimension composite view of the EO construct. The Hughes and Morgan (2007) EO scale recognises the multi-dimensionality of the EO construct. EO is not defined as a linear sum of its five sub-dimensions' measures. In addition, EO is not modelled as an aggregated or higher -order empirical construct. The final type of measure of EO is the "Type 11" second-order formative EO scale. Such a scale could be constructed based on the overall pool of items proposed by Hughes and Morgan (2007) scale for measuring EO. The five scales pertaining to EO's sub-dimensions could be used to create latent factors which would then be treated as formative indicators of the second-order construct. This study used the Miller/Covin and Slevin (1989) scale to measure EO. The eight measures of EO are aggregated to form the overall EO index. This is consistent with previous empirical studies on EO, debt and performance such Zampetakis et al. (2010: 897).

Five point Likert scale ranging from "1 strongly disagree to 5 strongly agree" was used. The question items are: (1) our company has 
introduced many new products and services over the last three years, (2) our company has made dramatic changes in the mix of products and services over the past three years, (3) our company has emphasized making major innovations in its products and services over the past three years, (4) over the past three years, this company has shown a strong proclivity for his risk projects (with chances of high return, (5) the company has emphasized taking bold, wide-ranging actions in positioning itself and its product (services) over the past three years, (6) the company has shown a strong commitment to research and development, technological leadership and innovation, (7) the company has followed strategies that allow it to exploit opportunities in its external environment, and (8) my firm has the tendency to be ahead of others in introducing products and services. Scores on the items were averaged to produce an overall EO index. A high score on the index indicates high involvement in $\mathrm{EO}$ and a low score indicates low involvement in $\mathrm{EO}$.

\section{Measuring Access to Debt Finance}

Following previous related empirical studies such as Zampetakis et al. (2010: 897) access to debt finance was measured by "Bank loans are easily accessible to us" and suppliers credit is easily accessible to us" on a five point Likert scale ranging from 1 strongly disagree to 5 strongly agree. The two measures of access to debt finance were aggregated to get a single access to debt finance score.

\section{Measuring Performance}

Performance was measured through both financial (objective) and non-financial (subjective) methods. This is consistent with similar empirical studies such as Leitao and Franco (2008). Financial measures focused on satisfaction with sales growth and profitability growth. Non-financial measures include performance relative to competitors and satisfaction with overall business performance. Five point Likert scale ranging from 1 strongly disagree to 5 strongly agree was used. The four performance measures were aggregated to get a combined performance index for each firm.

\section{RESULTS}

\section{Biographical Results}

300 questionnaires were distributed and 118 respondents participated in the survey after re-

Table 1: Results of confirmatory factor analysis of EO variables

\begin{tabular}{|c|c|c|c|}
\hline EO variables & $\begin{array}{l}\text { Factor } 1 \\
\text { Innovation }\end{array}$ & $\begin{array}{l}\text { Factor } 2 \\
\text { Proactiveness }\end{array}$ & $\begin{array}{c}\text { Factor } 3 \\
\text { Risk-taking }\end{array}$ \\
\hline $\begin{array}{l}\text { In the past five years, my firm has introduced many new lines } \\
\text { of products and services }\end{array}$ & 0.731 & & \\
\hline $\begin{array}{l}\text { In the past five years, changes in our products or service lines } \\
\text { have been quite dramatic }\end{array}$ & 0.684 & & \\
\hline $\begin{array}{l}\text { In general, my firm favour a strong emphasis on research and } \\
\text { development, technological leadership and innovations }\end{array}$ & 0.427 & & \\
\hline $\begin{array}{l}\text { In general, my firm has the tendency to be ahead of others in } \\
\text { introducing new products or services }\end{array}$ & & 0.717 & \\
\hline $\begin{array}{l}\text { In dealing with competition, my firm often try to initiate actions } \\
\text { to competitors, for which competitors respond }\end{array}$ & & 0.628 & \\
\hline $\begin{array}{l}\text { We believe that owing to the nature of the environment, bold } \\
\text { wide-ranging acts are necessary to achieve the firm's objectives }\end{array}$ & & & 0.724 \\
\hline $\begin{array}{l}\text { My firm typically adopts bold aggressive posture to maximize } \\
\text { the probability of exploring potential opportunities }\end{array}$ & & & 0.691 \\
\hline $\begin{array}{l}\text { My firm has a strong preference for high risk projects with } \\
\text { chances of high return }\end{array}$ & & & 0.593 \\
\hline Eigen value & 4.47 & 2.26 & 1.47 \\
\hline Percentage of variance explained & 29.67 & 27.46 & 19.23 \\
\hline Cronbach's alpha & 0.746 & 0.721 & 0.777 \\
\hline
\end{tabular}

Source: Principal components factor analysis with varimax rotation. Kaiser-Meyer-Olkin (KMO) test of sampling adequacy $=0.763 ;$ Barlett Test of Sphericity $($ BTS $)=477.062, p=0.001$ 
peated calls and visits. The response rate was $39.3 \%$. The gender distribution of the respondents revealed that $79 \%$ were males and $21 \%$ females. The age distribution of the respondents showed that no respondent was below the age of $20,5 \%$ of the respondents were between 21 $30,40 \%$ of the respondents were between the age of $31-40,43 \%$ of the respondents were between the age of $41-50$ and $12 \%$ above $50.81 \%$ of the respondents have post matric qualifications and close corporation is the dominant form of business ownership accounting for $62 \%$ of the respondents. The service sector including retail and wholesale accounted for $83 \%$ of the respondents and manufacturing $17 \%$. The number of employees was used to confirm if the firms belong to the SME sector. 79\% of the respondents have employees of between 2 and 25 and $21 \%$ of the respondents have employees between 26 and $50.76 \%$ of the respondents have been in operation for more than 10 years and $24 \%$ in operation for less than 10 years.

\section{Confirmatory Factor Analysis}

Table 1 depicts the results of the confirmatory factor analysis that was conducted to confirm the construct validity of the EO variables. Three factors with Eigen values greater than one were identified. Factor one is labelled as innovation and is made of three variables. Factor two is labelled as proactiveness and is made up of two variables. Factor three is labelled risk-taking and is made up of three variables. The Cronbach's alphas are greater than 0.700 for the three factors indicating the reliability of the factors.

\section{Descriptive Statistics and Hypotheses Testing}

Tables 2, 3, 4 and 5 depict the results of the descriptive statistics, correlation and regression.

Table 2: Means and standard deviations for the variables

\begin{tabular}{lcc}
\hline Variable & Mean & $\begin{array}{c}\text { Standard } \\
\text { deviation }\end{array}$ \\
\hline Entrepreneurial orientation & 3.27 & 0.84 \\
Debt finance & 2.88 & 0.76 \\
Performance & 3.34 & 0.81 \\
\hline
\end{tabular}

Source: Data Analysis
Table 3: Correlation results

\begin{tabular}{|c|c|c|c|c|}
\hline & & E.O & Debt & $\begin{array}{l}\text { Perfor } \\
\text { mance }\end{array}$ \\
\hline \multirow[t]{3}{*}{ E.O } & $\begin{array}{l}\text { Pearson } \\
\text { Correlation }\end{array}$ & 1 & $.883^{* *}$ & $.889^{* *}$ \\
\hline & Sig. (2-tailed) & & .000 & .000 \\
\hline & $\mathrm{N}$ & & 74 & 74 \\
\hline \multirow[t]{3}{*}{ Debt } & $\begin{array}{l}\text { Pearson } \\
\text { Correlation }\end{array}$ & $.883^{* *}$ & 1 & $.871^{* *}$ \\
\hline & Sig. (2-tailed) & .000 & & .000 \\
\hline & $\mathrm{N}$ & 118 & 118 & 118 \\
\hline \multirow[t]{3}{*}{$\begin{array}{l}\text { Perfor- } \\
\text { manc }\end{array}$} & $\begin{array}{l}\text { Pearson } \\
\text { ecorrelation }\end{array}$ & $.889^{* *}$ & $.871^{* * *}$ & 1 \\
\hline & Sig. (2-tailed) & .000 & .000 & \\
\hline & $\mathrm{N}$ & 118 & 118 & 118 \\
\hline
\end{tabular}

Source: Data Analysis. **Sig.>0.05

Table 4: Extract of the regression results EO, debt and performance

\begin{tabular}{lccc}
\hline Independent variables & Beta & $T$ & Sig \\
\hline Entrepreneurial orientation & .989 & 55.826 & .000 \\
Debt & .971 & 34.674 & .001 \\
\hline
\end{tabular}

Source:Data Analysis. dependent variable, performance. Sig. $>0.05$

Table 5: Extract of the regression results for EO and debt

\begin{tabular}{lccc}
\hline Independent variable & Beta & $T$ & Sig \\
\hline Entrepreneurial orientation & .983 & 45.789 & .001 \\
\hline
\end{tabular}

Source:Data analysis; Dependent variable: debt. Sig.>0.05

The means for EO, debt and performance are $3.27,2.88$ and 3.34 respectively. The correlation results between $\mathrm{EO}$ and debt is $(\mathrm{r}=0.883, \mathrm{p}=0.000)$. In addition, the regression results is $(\mathrm{B}=0.983$, sig=0.01). The results support the hypothesis that there is a positive relation ship between EO and access to debt finance. The findings are consistent with the results of previous empirical studies such as Zampetakis et al. (2010: 897). The correlation results between EO and performance are $(\mathrm{r}=0.889, \mathrm{p}=0.000)$. The regression results are $(B=0.989$, sig $=0.00)$ support the hypothesis that there is a positive relationship between $\mathrm{EO}$ and performance. The findings are consistent with previous empirical studies such as Aktan et al. (2008: 69) and Awang et al. (2010: 13). In addition, the correlation results $(\mathrm{r}=0.871, \mathrm{p}=0.00)$ and the regression results $(\mathrm{B}=0.971, \mathrm{P}=0.01)$ support a significant positive 
Table 6: Regression results for mediation

\begin{tabular}{lccccc}
\hline Model & \multicolumn{2}{l}{ Unstandardised coefficients } & & \multicolumn{2}{l}{$\begin{array}{l}\text { Standardised } \\
\text { coefficients }\end{array}$} \\
\cline { 2 - 3 } & $B$ & STD. Error & Beta & $T$ & Sig \\
\hline 1 (Constant) & -.174 & .066 & -.2 .632 & .010 & \\
DEBT & .025 & .0012 & .23 & -.233 & .003 \\
E.O & 1.070 & .104 & .011 & 10.334 & .000 \\
\hline
\end{tabular}

Source: Data Analysis, Dependant Variable: Performance, Sig. $>0.05$

relationship between access to debt finance and performance.

Table 6 depicts the results of the regression analysis to investigate mediation.

To determine whether access to debt finance will mediate the relationship between EO and the performance of SMEs, the four steps in establishing mediation as discussed by Kenny (2011: Internet) were used. Step 1: the initial variable is correlated with the outcome. Step 2: the initial variable is correlated with the mediator. Step 3: the mediator affects the outcome variable. Step 4: To establish that variable (M) completely mediates the $\mathrm{X}-\mathrm{Y}$ relationship, the effect of X on Y controlling for M (path c') should be zero. If all four of these steps are met, then the data are consistent with the hypothesis that variable $M$ completely mediates the $\mathrm{X}-\mathrm{Y}$ relationship, and if the first three steps are met but the Step 4 is not, then partial mediation is indicated. The results from Tables 3, 4 and 5 indicate significant positive correlations between EO and debt finance, EO and performance and debt finance and performance, thus meeting the first three requirements for mediation.

The results of step 4 (Table 6) the Beta of EO is not equal to zero (1.011). This indicates partial mediation. McKinnon (2008: 5) point out that the potential problems with Kenny approach is that it does not really test the significance of the indirect pathway - that X affects $\mathrm{Y}$ through the indirect pathway. A second problem is that the Kenny approach tends to miss some true mediation effects (Type II error). This is done by calculating the indirect effect and testing it for significance. The regression coefficient for the indirect effect represents the change in $\mathrm{Y}$ for every unit change in $X$ that is mediated by $M$. There are two ways to estimate the indirect coefficient. The first way was suggested by Judd and Kenny (1981) as cited in Kenny (2011) which involves computing the difference between two regression coefficients between step 1 and step 4.

The second approach suggested by Sobel (1982) as cited in Kenny (2011) calculates the indirect effect by multiplying two regression coefficients. The two coefficients are obtained from two regression models from step 4 and step 2. It is important to note that regardless of the approach one uses (that is, difference or product) one has to be sure to use unstandardized coefficients when conducting the computations Applying the Judd and Kenny Difference of Coefficients Approach, the results of the indirect effect is $(\mathrm{B}-\mathrm{B} 1=1.046-1.070=-0.024)$. Applying the Sobel product of coefficient approach, the indirect effect is $(\mathrm{B} 2 . \mathrm{B}=(-.025)(0.958)=-0.024)$. The Kenny and Judd difference of coefficients approach and the Sobel product of coefficients approach are supposed to yield identical values for the indirect effect (MacKinnon 2008: 5). The statistical significance of the indirect effect was tested. The Sobel test performs a statistical test to see if the indirect path from $\mathrm{X}$ to $\mathrm{Y}$ is statistically significantly different from zero. This is the same idea as the test providing support for partial mediation. The Sobel test tells whether a mediator variable significantly carries the influence of an independent variable to a dependent variable; that is, whether the indirect effect of the independent variable on the dependent variable through the mediator variable is significant.

The Sobel test statistic value is -4.338 at $95 \%$ confidence level and our critical value for the normal distribution used was a minus 1.96 since this is a two tailed test. Since the modulus of the Sobel test statistic value is greater that the modulus of the critical value it therefore means that the null hypothesis (the indirect effect of $\mathrm{X}$ 
on $\mathrm{Y}$ is zero) is rejected and we conclude that the indirect effect of the independent variable $(\mathrm{X})$ on the dependent variable(Y) through the mediator variable is significant. This indicates that the partial mediation is significant. Thus it can be concluded that access to debt partially mediates the relationship between EO and performance of SMEs.

\section{CONCLUSION}

Non-availability of debt finance or resource poverty is one of the critical failure factors of SMEs in South Africa. The results indicate that EO is positively associated with access to debt finance and thus can be a way to reduce the financial constraints faced by some SMEs. In addition, EO is positively associated with the performance of SMEs and thus can be one of the mechanisms to reduce the weak performance and high failure rate of SMEs in South Africa. Finally, the results indicate that access to debt finance partially mediates the relationship between EO and the performance of SMEs. The findings of this study are consistent with the theoretical foundation that EO can improve the firm performance. The findings are also consistent with empirical literature that EO can improve access to debt finance by SMEs.

\section{RECOMMENDATIONS}

It is important for SMEs to imbibe the dimensions of EO which are risk-taking, competitive aggressiveness, autonomy, proactiveness and innovativeness to improve access to debt and performance. Before taking any action, the SME needs to evaluate its levels of entrepreneurial orientation. This could be done through an internal audit. If a lack in its EO is found, the SME needs thus to identify the factors that need to be developed. EO needs to be incorporated within the structure of the SMEs, through a top-down management style. Strategic leadership and support by SME owners are very important to develop entrepreneurship culture. The management of the SME must also leave some available place among the workforce for initiative making, autonomy and communication to develop EO. SME owners should organize their firms in a way in which entrepreneurship can flourish in the form of new products, ventures, and process ideas. Reward system both monetary and non-monetary for staff of SMEs must encourage entrepreneurship. SME owners must provide the leadership style that will allow innovation and creativity to thrive. Government agencies responsible for SMEs such as the Small Business Development Agency, Provincial Development Corporations, The National Youth Development Agency should organise training and seminars for SMEs on the dimensions of EO.

\section{LIMITATIONS OF THE STUDY}

This study used an aggregated unidimensional measure of EO as provided by the Miller/Covin and Slevin (1989) measure of EO. This approach neglects the impact of the individual components (multi-dimensional measure) of EO on access to debt and performance.

\section{AREAS FOR FURTHER STUDIES}

Further studies can use the Hughes and Morgan (2007: 655) EO scale to empirically investigate the individual effects of the five dimensions of EO (risk-taking, innovativeness, proactiveness, competitive aggressiveness and autonomy) on access to debt and performance of SMEs. In addition, other studies can investigate how firm characteristics such as the age of the firm, the industry and entrepreneurial characteristics such as the managerial competency of the owner can impact on entrepreneurial orientation and performance of SMEs.

\section{REFERENCES}

Abor A, Quartey P 2010. SME development in Ghana and South Africa. Int Res J of Fin and Econ, 39: 218-228.

Adeniran T, Johnston A 2011. Investigating the Level of Internet capabilities of South African Small and Medium Enterprises in Changing Environments. From <www.zaw3.co.za/index.php/ZAWWW/2011/paper/view/450> (Retrieved August 15, 2011).

Aktan B, Bulut C 2008. Financial performance impacts of corporate entrepreneurship in emerging markets: A case of Turkey. Euro J of Econ, Fin and Admin Sciences, 12: 69-79.

Atieno R 2009. Linkages, access to finance and the performance of small-scale enterprises in Kenya. $J$ of Acc and Bus Res, 3(1): 33-48.

Awang A, Ahmad ZA, Asghar ARS, Subari KA 2010. Entrepreneurial orientation among Bumiputera 
Small and Medium Agro-Based Enterprises (BSMAEs) in West Malaysia: Policy implication in Malaysia. Int $J$ of Bus and Manag, 5(5): 13143.

Bartholdy J, Mateus C 2006. Debt and Taxes: Evidence from Bank Financed Small and Medium Enterprises. From< http://www.fma.org/Chicago/ papers/tax-payers-wp-version-jan-with-tablespdf> (Retrieved May 25, 2011).

Blumberg BF, Letterie WA 2008. Business starters and credit rationing in small business. Small Bus Econ, 3(1): 187-200.

Bowen M, Morara M, Mureithi S 2009. Management of business challenges among small and micro enterprises in Nairobi-Kenya. KCA $J$ of Bus Manag, 2(1): 16-31

Callaghan C, Venter R 2011. An investigation of the entrepreneurial orientation, context and entrepreneurial performance of inner-city Johannesburg street traders. Southern African Bus Review, 15(1): $28-48$.

Chen CN, Tzeung LC, Ou WM, Chang KT 2008. The relationship among social capital, entrepreneurial orientation, organizational resources and entrepreneurial performance for new ventures. Contemporary Manag Res, 3(3) 213-232.

Covin JG, Slevin DP 1989. Strategic management of small firms in hostile and benign environments. Strategic Manag J, 10: 75-87.

Covin JG, Wales WJ 2011. The measurement of entrepreneurial orientation. Entr Theory and Practice, 1(1): 1-26.

Covin JG, Lumpkin GT 2011. Entrepreneurial orientation theory and research: Reflections on a needed construct. Entr Theory and Practice, 35(5): 855872.

Eriotis NP, Franguoli Z, Neokosmides ZV 2002. Profit margin and capital structure: An empirical relationship. J of App Bus Res, 18(2): 85-89.

Fairoz FM, Hirobumi T, Tanaka Y 2010. Entrepreneurial orientation and business performance of small and medium scale enterprises of Hambantota District Sri Lanka. Asian Soc Science, 6(3): 34-46.

Farrington SM, Matchaba-Hove MTM. 2011. The Influence of Entrepreneurial Orientation on Small Business Success. From <www.saims2011. ukzn. ac.za/Libraries/Final_Programme/Final_SAIMS Programme_2011.sflb.ashx> (Retrieved March $15,2011)$

Gordhan P 2011. Low Interest Rates May Not Be Good for SA. From <www.mg.co.za/article/2011-10-04gordhan-low-interest-rates-may-not-be-in-sasbest/> (Retrieved August 11, 2011).

Groenewald D, Van Vuuren J 2011. Conducting a corporate entrepreneurial health audit in South African short term insurance businesses. $J$ of Contemporary Manag, 8: 1-33

Hadlock CJ, James CM 2002. Do banks provide financial slack? The J of Fin, 57(3): 1383-1419.

Hartsfield S, Johansen D, Knight G 2008. Entrepreneurial orientation, strategy, marketing capabilities and the performance of born global firms. Int Bus Res Teaching and Prac, 2(1): 1238 .
Herrington M, Kew J, Kew P 2009. Global Entrepreneurship Monitor, South African Report. From <www.gbs.nct.ac.za/gbswebb/userfiles/gem southafrica2000pdf > (Retrieved 15 May, 2011).

Haung KP, Wang KU, Chen KH, Yien JM 2011. Revealing the effects of entrepreneurial orientation on firm performance. A conceptual approach. $J$ of Applied Sciences, 11(6): 3049-3052.

Hughes M, Morgan RE 2007. Deconstructing the relationship between entrepreneurial orientation and business performance at the embryonic stage of firm growth. Industrial Marketing Manag, 36(5): 651-661.

Hung KP, Chiang YH 2010. Open innovation proclivity, entrepreneurial orientation and perceived firm performance. Int J of Technology Manag, 3(4): 257-274.

Ireland RD, Covin JG, Kuratko DF 2009. Conceptualizing corporate entrepreneurship strategy. Entr Theory and Prac, 33(1): 19-46.

Kenny DA 2011. Mediation. From < http: //davidakenny.net/cm/mediate.htm > (Retrieved July 19, 2011).

Khandwalla PN 1976/1977. Some top management styles, their context and performance. Organ and Admin Sciences, 7: 21-51.

Kriel P 2008. The Nature of Corporate Entrepreneurship in the South African Liquor Market. From $<$ http://upetd.up.ac.za/thesis/available/etd03122010154055/unrestricted/dissertation.pdf> (Retrieved March 22, 2011).

Leitao J, Franco M 2008. Individual Entrepreneurship Capacity and Performance of SMEs. From < http: //ssrn.com/abstract $=1118257>($ Retrieved June $14,2011)$.

Li Y, Zhao Y, Tan J, Liu Y 2008. Moderating effects of entrepreneurial orientation on market orientationperformance linkage: Evidence from Chinese small firms. J of Small Bus Manag, 46(1): 113133.

Ligthelm A 2011. Soweto Businesses Struggling. From $<$ www.news24.com/SouthAfrica/News/Sowetobusinesses-struggling-20111030> (Retrieved October 31, 2011).

Lucey BM 2010. Determinants of capital structure of Irish SMEs. Small Bus Econ, 35(3): 1-25

Lumpkin GT, Dess GG 1996. Clarifying the entrepreneurial orientation construct and linking it to performance. Academy of Manag Review, 21(1): $135-172$.

Mackinnon DP 2008. Introduction to Statistical Mediation Analysis. New Jersey: Lawrence Erlbaum Associates, Inc.

Miller D, Friesen PH 1982. Innovation in conservative and entrepreneurial firms: Two models of strategic momentum. Strategic Manag J, 3(1): 1-25.

Miller D 1983. The correlates of entrepreneurship in three types of firms. Manag Science, 29(7): 770791.

Mintzberg H 1973. Strategy-making in three modes. California Manag Review, 16(2): 44-53.

Modigliani F, Miller MH 1963. Corporate income taxes and the cost of capital: A correction. American Econ Review, 53(3): 433-444. 
Moreno AM, Casillas JC 2008. Entrepreneurial orientation and growth of SMEs: A causal model. Entr Theory and Prac, 33(3): 507-528

Mukiri MG 2011. Determinants of Access to Bank Credit by Micro and Small Enterprises in Kenya. From <www.growinginclusivemarkets.org/media/ publications/determinants_of_access_to_bank credit_by_micro_and_small_enterprises_in_kenya.pdf> (Retrieved November 10, 2011).

Negash M 2002. Corporate tax and capital structure: Some evidence and implications. The Invest Analysts J, 56(2): 118-130.

Pahad A 2008. South-South Cooperation and Poverty Reduction. From <http://74.125.77.132/search > (Retrieved July 26, 2011).

Razak RA 2011. Entrepreneurial orientation as a universal remedy for the receding productivity in Malaysian small and medium enterprises: A theoretical perspective. Int Jl of Bus and Soc Science, 2(19): 249-257.

Rodrigues RG 2008. Entrepreneurial Orientation, Market Orientation, and Performance in Manufacturing SMEs. In RENT - Research in Entrepreneurship and Small Business. From <http://www.mendeley.com/research/the-effectsof-entrepreneurial-orientation-and-marketinginformation-on-the-performance-of-smes/ (Retrieved May 21, 2011).

Rogerson CM 2008. Tracking SMME development in South Africa: Issues of finance, training and regulatory environment. Urban Forum, 19(1): 61-81.

Scheepers MJ, Hough J, Bloom JZ 2008. Nurturing the corporate entrepreneurship capability. Southern African Bus Review, 12 (3): 50-75.
South African Reserve Bank 2011. Rates. From <http:/ /www.resbank.co.za/Research/Rates/Pages/RatesHome.aspx> (Retrieved December 12, 2011).

South African Venture Capital Association 2008. Venture Capital Funding. From <http: //www.savca.co.za/ kpmgsurvey/default.aspn > (Retrieved May 20, 2011 ).

Statistics South Africa 2012. Quarterly Labour Force Survey. From <http://www.statssa.gov.za/publication/find publication asp> (Retrieved March 18, 2012)

Swidi AK, Mahmood R 2011. How does organizational culture shape the relationship between entrepreneurial orientation and the organizational performance of banks? European J of Soc Sciences, 20(1): 28-46.

Tang J, Tang Z, Marino LD, Zhang Y, Li Q 2008. Exploring an inverted u-shape relationship between entrepreneurial orientation and performance in Chinese ventures. Entr Theory Prac, 32(1): 219-239.

Van Geenhuizen M, Middel R, Lassen AH 2008. Corporate Entrepreneurship in SMES During the Search for Discontinuous Innovations. From <http:// vbn.aau.dk/files/14927322/Corporate Entrepreneurship_in_SMEs_during_the_Search_ for_Discontinuous__Innovations.pdf $>$ (Retrieved June 27, 2011).

Zampetakis LA, Vekinia M, Moustakis AV 2010. Entrepreneurial orientation, access to financial resources, and product performance in the Greek commercial TV industry. The Service Industries $J, 31(6): 897-910$

Zou H, Chen X, Wang DT 2009. How new ventures grow? Firm capabilities, growth strategies and performance. Int J of Res in Marketing, 26 (4): 294-303. 
